Michał Marcin Kobierecki

Uniwersytet Łódzki

\title{
Dyplomacja sportowa w procesie łagodzenia konfliktów międzynarodowych*
}

DOI: 10.19195/1643-0328.22.13

Słowa kluczowe: dyplomacja sportowa, konflikty międzynarodowe, dyplomacja publiczna, sport i polityka

\section{Wprowadzenie}

W niniejszym artykule podjęte zostały rozważania na temat dyplomacji sportowej, której celem jest łagodzenie międzynarodowych konfliktów politycznych. Owe rozważania integrują dwie zasadnicze części. Pierwsza z nich dotyczy kategorii poznawczej, jaką jest dyplomacja sportowa, obejmując jej wyjaśnienie z uwzględnieniem różnych podejść. Druga część dotyczy tego, w jaki sposób dyplomacja sportowa jest w stanie doprowadzić do złagodzenia międzynarodowych konfliktów politycznych. Podjęta zostanie jednocześnie próba odpowiedzi na pytanie badawcze dotyczące możliwości i sposobów wykorzystania sportu w celu łagodzenia konfliktów, do których dochodzi na arenie międzynarodowej.

Celem niniejszego przedsięwzięcia badawczego jest przedstawienie sposobów działań z zakresu dyplomacji sportowej, które podejmowane są, aby przeciwdziałać konfliktom politycznym o charakterze międzynarodowym. Artykuł ma charakter teoretyczny, aczkolwiek wyszczególnienie zostało dokonane na podstawie obserwacji konkretnych przejawów tego typu dyplomacji.

O sytuacji konfliktowej można mówić wówczas, gdy dążenia przynajmniej dwóch podmiotów pozostają z sobą w sprzeczności, co wynika z przyjętych przez nie celów ${ }^{1}$. Stronami konfliktów politycznych są podmioty polityki, a więc państwa, partie polityczne oraz inne organizacje społeczne, które biorą udział w realizacji polityki państwa bądź

* Publikacja zrealizowana dzięki finansowaniu Narodowego Centrum Nauki w ramach projektu badawczego nr 2015/19/D/HS5/00513.

1 J. Ziółkowski, Wrogość w stosunkach politycznych. Modelowa analiza funkcjonalna, Warszawa 2013, s. 111. 
starają się na nią wpływać ${ }^{2}$ a także jednostki, o ile posiadają zdolność do podejmowania działań politycznych ${ }^{3}$. Jeżeli dochodzi do konfliktu między państwami, należy mówić o konflikcie międzynarodowym, który definiowany jest jako układ stosunków pomiędzy podmiotami prawa międzynarodowego, charakteryzujący się sprzecznością stanowisk oraz występowaniem rzeczywistego lub wyobrażonego zagrożenia, jeżeli chodzi o nadrzędne wartości, interesy i cele tych podmiotów ${ }^{4}$. Stąd też zasadna wydaje się analiza nomologiczna metod rozwiązywania międzynarodowych konfliktów politycznych.

\section{Uwagi o pojęciu dyplomacji sportowej}

Dyplomacja sportowa jest pojęciem od niedawna analizowanym zagranicą i w związku z tym nowym, jeżeli chodzi o nauki humanistyczno-społeczne w Polsce. Jest to zarazem określenie dosłowne, chociaż jeszcze nieutrwalone w przyzwyczajeniach specjalistów w zakresie stosunków międzynarodowych, a także trudne do jednoznacznego zdefiniowania, toteż wielu autorów preferuje różne sposoby jego rozumienia, niekiedy nie w pełni koherentne.

Na uwagę w pierwszej kolejności zasługują próby ustaleń w kwestii statusu i funkcji podmiotów dyplomacji sportowej. Czy chodzi tu wyłącznie o państwa, czy również o innych aktorów społeczno-politycznych, którzy mogą realizować w mniejszym bądź większym stopniu dyplomację sportową?

Zwolennikiem pierwszego stanowiska jest chociażby Martin Polley, dla którego dyplomacja sportowa oznacza wykorzystywanie przez rządy sportu do wyrażania opinii dotyczących innych krajów ${ }^{5}$. Autorzy postrzegający dyplomację sportową jako atrybut państw różnią się między sobą co do jej dokładnego zakresu znaczeniowego. W potocznym rozumieniu najczęściej jest ona kojarzona $\mathrm{z}$ „dyplomacją pingpongową” pomiędzy Stanami Zjednoczonymi a Chińską Republiką Ludową, która doprowadziła do poprawy relacji pomiędzy tymi krajami. Właśnie w taki sposób dyplomację sportową definiuje David Rowe, dla którego jest ona stosunkowo bezpiecznym, łagodnym sposobem „nawiązywania przyjaźni” oraz zażegnywania konfliktów ${ }^{6}$.

Część autorów rozumie tę kategorię w sposób szerszy, określając dyplomację sportową jako sytuację, kiedy sport jest wykorzystywany do poprawiania, a czasem także pogarszania stosunków politycznych pomiędzy dwoma bytami ${ }^{7}$. W tym ujęciu dyplomacja sportowa zarówno obejmuje działania promujące pokój i współpracę, jak też stanowi

2 L. Sobkowiak, Konflikt polityczny, [w:] Encyklopedia Politologii, t. 1, red. W. Sokół, M. Żmigrodzki, Kraków 1999, s. 159; M. Chmaj, Podmiotowość polityczna, [w:] Encyklopedia Politologii..., s. 225.

3 A. Czajowski, Decydowanie w polityce, Wrocław 2013, s. 143.

${ }^{4}$ K. Pawłowski, Spory i konflikty międzynarodowe, [w:] Międzynarodowe stosunki polityczne, red. M. Pietraś, Lublin 2007, s. 351.

${ }^{5}$ M. Polley, Sports History. A Practical Guide, New York 2007, s. 71, 96.

6 D. Rowe, Global Media Sport. Flows, Forms and Futures, London 2011, s. 115.

7 A. Saxena, The Sociology of Sport and Physical Education, New Delhi 2011, s. 25. 
narzędzie konfrontacji ideologicznej bądź wyraz demonstracji siły i władzy ${ }^{8}$. Dyplomacja sportowa może bowiem polegać także na wykorzystywaniu sportu do eksponowania niezgody pomiędzy narodami ${ }^{9}$.

Oba podejścia dotyczące rozumienia pojęcia dyplomacji sportowej państw dostrzegają jej rolę w łagodzeniu i przezwyciężaniu konfliktów międzynarodowych, natomiast zgodnie z szerszym ujęciem dyplomacja sportowa obejmuje także wykorzystywanie sportu jako elementu walki politycznej. W związku z tym można wyróżnić pozytywną i negatywną dyplomację sportową. Ta ostatnia wykorzystuje sport w celu potępienia danego kraju ${ }^{20}$.

Coraz częściej uznaje się, iż dyplomacja sportowa jest atrybutem nie tylko państw, ale także innych aktorów społeczno-politycznych - w nawiązaniu do ujęcia zaprezentowanego przez Stuarta Murraya i Goeffreya Pigmana, którzy wyróżnili dwa typy dyplomacji sportowej. Pierwszy z nich dotyczy sytuacji, w których międzynarodowy sport jest wykorzystywany przez rządy jako instrument dyplomatyczny. Drugi typ to „międzynarodowy sport jako dyplomacja”. Dyplomacja sportowa obejmuje dyplomatyczną reprezentację, komunikację i negocjacje pomiędzy aktorami niepaństwowymi (a czasem także państwami), które uobecniają się wskutek toczącej się międzynarodowej rywalizacji sportowej ${ }^{11}$. Podobne stanowisko prezentuje specjalista z zakresu dyplomacji publicznej James Pamment, który wyróżnia takie aspekty dyplomacji sportowej, jak: po pierwsze spotkania na szczycie, obchody, symbolizm i korzyści wizerunkowe związane z dużymi wydarzeniami sportowymi i sportem elitarnym; po drugie - wielostronna dyplomacja i pseudodyplomacja niepaństwowych instytucji sportowych związana z członkostwem, organizacją, uznaniem i dostępem do zasobów; po trzecie - sport jako nośnik wartości, norm i standardów, promowanych jako wiedza techniczna i udział w praktykach spolecznych ${ }^{12}$.

Dyplomacja sportowa bardzo często postrzegana jest jako element bądź też subkategoria dyplomacji publicznej. Według Jacquie L’Etang, która jednocześnie nawiązuje do rozważań na temat roli sportu w kształtowaniu wizerunku międzynarodowego państwa, dyplomacja sportowa to część dyplomacji publicznej obejmująca komunikację oraz nation-branding ${ }^{13}$. Według Beaty Ociepki sport odgrywa istotną rolę w dyplomacji publicznej w związku z możliwością wykorzystania go do budowania międzynarodowej

${ }^{8}$ R.B. Santos, A.M. Mestre, F.R. de Megalhāes, Sports Law in Portugal, Alphen aan den Rijn 2011, s. 21.

9 P.A. D'Agati, The Cold War and the 1984 Olympic Games. A Soviet-American Surogate War, New York 2013, s. 13.

10 B. Houlihan, Politics and Sport, [w:] Handbook of Sports Studies, red. J. Coakley, E. Dunning, London 2000, s. 219; A.D. Downes, Forging Africa-Caribbean Solidarity within the Commonwealth? Sport and Diplomacy during the Anti-Apartheid Campaign, [w:] Diplomatic Games. Sport, Statecraft, and International Relations since 1945, red. H.L. Dichter, A.L. Johns, Lexington 2014, s. 118.

11 S. Murray, G.A. Pigman, Mapping the relationship between international sport and diplomacy, „Sport in Society" 17, 2014, nr 9, s. 1099.

12 J. Pamment, Rethinking diplomatic and development outcomes through sport: Toward a participatory paradigm of multi-stakeholder diplomacy, „Diplomacy \& Statecraft” 27, 2016, nr 2, s. 234.

13 J. L’Etang, Sports Public Relations, Los Angeles 2013, s. 81-82. 
pozycji państwa ${ }^{14}$. Dyplomacja publiczna, mimo że z założenia służy państwom i wpisuje się w ich bezpośrednią aktywność, bardzo często realizowana jest niejako poza nimi, mianowicie w szerszym wymiarze kontaktów międzyludzkich. Stąd też określana jest niekiedy jako dyplomacja międzyludzka ${ }^{15}$.

Należy stwierdzić, iż dyplomacja sportowa może być realizowana przez różne podmioty, w tym także organizacje i kluby sportowe, oraz konkretnych ludzi, a więc również sportowców i kibiców. Niemniej jednak państwa okazują się być dominującym podmiotem. Nie ma zgody, czy dyplomacja sportowa dotyczy wyłącznie realizacji funkcji pozytywnej związanej z preferowaniem lepszych stosunków pomiędzy państwami, czy obejmuje także działanie odwrotne. Podjęte w niniejszym artykule rozważania dotyczą jedynie pozytywnej dyplomacji sportowej.

\section{Sposoby wykorzystywania sportu do łagodzenia konfliktów międzynarodowych}

Dyplomacja sportowa jest narzędziem chętnie wykorzystywanym w celu przeciwdziałania konfliktom i sporom występującym pomiędzy państwami. Dzieje się tak, ponieważ sport, przynajmniej z pozoru, jest postrzegany jako apolityczna sfera rzeczywistości. Taki ogląd sportu lansują międzynarodowe federacje sportowe, a zwłaszcza Międzynarodowy Komitet Olimpijski. Wskutek tego możliwe jest w sferze sportu podejmowanie decyzji i działań politycznych, które z przyczyn prestiżowych i honorowych byłyby trudne do podjęcia bez wykorzystania swoistego „buforu”, za jaki nierzadko uważa się sport.

Istnieją różne sposoby wykorzystywania dyplomacji sportowej w celu łagodzenia międzynarodowych konfliktów politycznych. Do najważniejszych należy organizowanie wymian sportowych. Ich celem jest kształtowanie bardziej pozytywnego wzajemnego nastawienia społeczeństw zaangażowanych krajów. Bywają one także wykorzystywane w celu aranżowania spotkań dyplomatycznych. Nie są to bynajmniej kategorie wzajemnie wykluczające się, jako że często zdarzało się, iż wydarzenia sportowe były wykorzystywane przez polityków do aranżowania spotkań w imię poprawiania wzajemnego postrzegania państw przez ich społeczeństwa.

\section{Sport a kształtowanie sympatii między narodami}

Do najbardziej znanych przejawów dyplomacji sportowej ukierunkowanej na zbliżenie pozostających w konflikcie państw należy „dyplomacja pingpongowa” między Stanami Zjednoczonymi a Chińską Republiką Ludową. Długotrwały konflikt pomiędzy tymi krajami miał podłoże ideologiczne. Jednakże z uwagi na zmieniającą się sytuację geopolityczną i „kruszący” się sojusz radziecko-chiński w interesie obu krajów było zała-

14 B. Ociepka, Miękka siła i dyplomacja publiczna Polski, Warszawa 2013, s. 13.

15 Por. J.G. Payne, Reflections on public diplomacy: People-to-people communication, „American Behavioral Scientist" 53, 2009, nr 4, s. 603-604. 
godzenie sytuacji konfliktowej i doprowadzenie do wzajemnego zbliżenia. Stąd też od początku lat 70. XX w. podejmowano kroki zmierzające do zaaranżowania jakiegoś zdarzenia zapoczątkowującego spotkania dyplomatyczne na wysokim szczeblu. Istniały jednak okoliczności uniemożliwiające nawiązanie otwartych rozmów, m.in. fakt, iż od wielu lat oba kraje były wzajemnie demonizowane w opinii społecznej. Nawiązanie dialogu utrudniały także sojusz amerykańsko-tajwański oraz względy prestiżowe związane z ewentualnym fiaskiem zbliżenia. Prowadzono zatem „dyplomację tajną”. Pośrednikami okazali się dyplomaci pakistańscy ${ }^{16}$. Jednak taka forma dialogu miała pewne ograniczenia. Wykorzystano więc okoliczność, iż reprezentacje obu krajów brały udział w odbywających się w japońskiej Nagoi w marcu i kwietniu 1971 r. mistrzostwach świata $\mathrm{w}$ tenisie stołowym ${ }^{17}$. Wówczas doszło do spotkań pomiędzy przedstawicielami ekip chińskiej i amerykańskiej, podczas których Amerykanie zostali zaproszeni do wzięcia udziału w pokazowych meczach tenisa stołowego na terenie Chin ${ }^{18}$. W dniu 10 kwietnia 1971 r. przybyło do Chin 9 amerykańskich tenisistów stołowych wraz z 4 działaczami i 2 osobami towarzyszącymi, którzy zostali bardzo ciepło przyjęci. Wskutek tego doszło do dwóch meczów towarzyskich ${ }^{19}$. Kilka godzin później ogłoszono w Waszyngtonie zniesienie trwającego od 22 lat embarga w handlu z Chinami ${ }^{20}$. Wkrótce doszło także do dwóch wizyt w Chinach Sekretarza Stanu USA Henry'ego Kissingera, a w lutym 1972 r. prezydenta USA Richarda Nixona.

Jak się okazało, owa „dyplomacja pingpongowa” w pośredni sposób doprowadziła do spotkania polityków na wysokim szczeblu. Jednak wydaje się, iż w większym stopniu przyczyniła się do ogólnej poprawy wzajemnego postrzegania poszczególnych krajów przez ich społeczeństwa. Według Murraya i Pigmana tego rodzaju dyplomacja sportowa miała być narzędziem umożliwiającym przetestowanie tego, czy opinia publiczna w obydwu krajach zaakceptowałaby bardziej formalne dyplomatyczne otwarcie dotychczas zamrożonych relacji ${ }^{21}$.

Można sądzić, iż „dyplomacja pingpongowa” okazała się znamiennym przykładem wykorzystania sportu do poprawy wzajemnego nastawienia społeczeństw skonfliktowanych państw. Okoliczności związane z dotychczasowymi relacjami pomiędzy Chinami a Stanami Zjednoczonymi, a także szereg uwarunkowań zewnętrznych sprawiały, iż obydwa kraje potrzebowały przynajmniej pozornie odseparowanej od polityki sfery współpracy, która mogłaby okazać się „katalizatorem” i przynieść poprawę relacji o charakterze politycznym. Taką sferą okazał się sport. „Dyplomacja pingpongowa” była pierwszym przejawem wykorzystania sportu do poprawy stosunków pomiędzy wrogi-

16 Y. Xia, Negotiating with the Enemy. U.S.-China Talks during the Cold War, 1949-1972, Bloomington 2006, s. 154-155.

17 G. Xu, Olympic Dreams. China and Sports 1895-2008, Cambridge 2008, s. 127; R. Espy, The Politics of the Olympic Games, Berkeley 1979, s. 127-128.

18 G.A. Pigman, Contemporary Diplomacy, Cambridge 2010, s. 193.

19 A. Axelrod, The Real History of the Cold War. A New Look at the Past, New York 2009, s. 378; G. Xu, op. cit., s. 135.

20 Y. Xia, op. cit., s. 153-154; G.A. Pigman, op. cit.

21 S. Murray, G.A. Pigman, op. cit., s. 1101. 
mi państwami, jednak jej sukces na tyle silnie uobecnił się w świadomości decydentów politycznych, iż jeszcze wielokrotnie starano się wykorzystać sport w podobny sposób. Amerykańsko-chińska wymiana w tenisie stołowym z 1971 r. ukazała bowiem nieznany wcześniej potencjał kontaktów sportowych, jeśli chodzi o kształtowanie stosunków politycznych.

Na uwagę zasługuje także kwestia stosunków Stanów Zjednoczonych ze Związkiem Radzieckim w okresie zimnej wojny. Konflikt ideologiczny pomiędzy nimi był na tyle silny, iż trudno mówić o potencjalnej chęci jego przezwyciężenia, a nawet złagodzenia. Jednocześnie kraje te nigdy nie zerwały stosunków dyplomatycznych, toteż utrzymywały swoje placówki dyplomatyczne w stolicach drugiego państwa. Istniał także szereg kanałów ewentualnego dialogu, jak chociażby Rada Bezpieczeństwa ONZ. Sport nie był więc potrzebny do aranżowania spotkań dyplomatycznych, tak jak w przypadku opisanej wcześniej „dyplomacji pingpongowej”. Tym niemniej, szczególnie w okresach odprężenia, w USA i ZSRR dostrzegano konieczność nawiązywania kontaktów o niekoniecznie politycznym charakterze. I w tym przypadku użyteczny okazał się sport.

Pozytywna dyplomacja sportowa, do jakiej dochodziło pomiędzy USA a ZSRR, dotyczyła przede wszystkim organizowania towarzyskich serii meczów. Negocjacje dotyczące możliwości odbycia ich prowadzone były od $1952 \mathrm{r}^{22}$ Rozmawiali na ten temat także prezydent USA Dwight Eisenhower i premier ZSRR Nikołaj Bułganin podczas spotkania w Genewie w 1955 r. Uzgodniono wówczas organizację szeregu wymian kulturalnych, w tym serię corocznych spotkań lekkoatletycznych ${ }^{23}$. Negocjacje zostały zwieńczone podpisaniem w 1958 r. porozumienia, potocznie nazywanego „kulturalnym” lub Lacy-Zarubin, które zakładało wymianę w wielu sferach, takich jak: nauka i technologia, rolnictwo, sport itp. ${ }^{24}$ Porozumienie to obejmowało organizację wymian w ciągu najbliższych kilku lat, jednak w późniejszym czasie było wielokrotnie ponawiane.

Wymiany sportowe pomiędzy Stanami Zjednoczonymi a Związkiem Radzieckim dotyczyły bardzo wielu sportów. Szczególne znaczenie przypisuje się kontaktom w lekkoatletyce i koszykówce. W pierwszej z tych dyscyplin miała miejsce seria mitingów z udziałem zawodników i zawodniczek z obu krajów. Pierwszy z nich odbył się w Moskwie w lipcu 1958 r. i trwał 2 dni. W jego trakcie można było dostrzec liczne przejawy eksponowania przyjacielskiego nastawienia. Radzieccy kibice mieli oklaskiwać zarówno zawodników radzieckich, jak i amerykańskich. Równie przyjacielsko mieli się wobec siebie odnosić sportowcy ${ }^{25}$. Toteż pomimo konfliktu ideologicznego podczas amerykańsko-radzieckich kontaktów sportowych widoczne były przyjacielskie symbole i gesty. W prasie radzieckiej pojawiały się także pochlebne wobec Amerykanów artykuły. Zgodnie z założeniami dyplomacji publicznej kontakty takie miały prowadzić do wzbudzenia wzajemnej sympatii w społeczeństwach obu krajów.

22 J.M. Turrini, "It was communism versus the free world": The USA-USSR dual track meet series and the development of track and field in the United States, 1958-1985, „Journal of Sport History” 28, 2001, nr 3, s. 429.

${ }_{23}$ R.O. Davies, Sport in American Life. A History, Malden 2007, s. 328.

24 L.A. Belmonte, Selling the American Way. U.S. Propaganda and the Cold War, Philadelphia 2008, s. 83.

25 R.O. Davies, op. cit.; V. Rosenberg, Soviet-American Relations, 1953-1960. Diplomacy and Cultural Exchange During the Eisenhower Presidency, Jefferson 2005, s. 149. 
Do kolejnego spotkania amerykańsko-radzieckiego w lekkoatletyce doszło w czerwcu 1959 r. w Filadelfii ${ }^{26}$, a według Williama Bakera mecz ten stworzył „podwaliny” pod wizytę Nikity Chruszczowa w USA 3 miesiące później ${ }^{27}$. W kolejnych latach bilateralne amerykańsko-radzieckie spotkania lekkoatletyczne odbywały się corocznie, raz w jednym, raz w drugim kraju. Do najsłynniejszych należy wizyta radzieckich lekkoatletów w Stanford, w lipcu 1962 r. $^{28}$ W 1966 r., na skutek zaostrzenia relacji między krajami w związku z wojną w Wietnamie, ciągłość wymian lekkoatletycznych została przerwa$\mathrm{na}^{29}$. Spotkania wznowiono w 1969 r. i rozgrywano je nieprzerwanie do 1985 r., aczkolwiek nie cieszyły się już tak wielkim zainteresowaniem ${ }^{30}$.

W kontekście pozytywnej dyplomacji sportowej między ZSRR a USA duże znaczenie przypisuje się także kontaktom drużyn koszykarskich, które obejmowały organizację serii meczów. W 1958 r. w ZSRR drużyna USA rozegrała 6 spotkań przeciwko najlepszym radzieckim drużynom klubowym oraz reprezentacji tego kraju. Był to początek serii meczów, aczkolwiek nie odbywały się one w regularnych odstępach czasowych. Mimo że wymiany, zgodnie z założeniami, miały służyć promocji pokojowych relacji, to jednak dochodziło $\mathrm{w}$ ich trakcie do przypisywania politycznego znaczenia zwycięstwom sportowym $^{31}$. Należy w związku z tym podkreślić, iż umiejętnie zastosowana „pozytywna" dyplomacja sportowa była w stanie przyczynić się do poprawy postrzegania kraju tradycyjnie uważanego za wroga. Jednakże nie bez znaczenia było ryzyko pojawiania się nastrojów nacjonalistycznych, co mogło przyczynić się do odwrotnego od zamierzonego efektu podjętych działań. Sport potrafi bowiem rozbudzać bardzo rozbieżne emocje. Z jednej strony, zgodnie $\mathrm{z}$ ideą olimpijską, pokojowa rywalizacja $\mathrm{w}$ duchu fair play powinna prowadzić do pobudzania pozytywnych postaw względem przedstawicieli innych państw. Wydaje się to być istotą dyplomacji sportowej jako narzędzia zażegnywania konfliktów między państwami. Z drugiej jednak strony, sport bywa często postrzegany jako sfera emanacji nacjonalizmu i agresji. Kluczem do skutecznego zastosowania pozytywnej dyplomacji sportowej jest uniknięcie tego drugiego.

\section{Aranżowanie spotkań dyplomatycznych podczas wydarzeń sportowych}

Wydarzenia sportowe często były wykorzystywane przez przywódców skonfliktowanych państw do organizowania spotkań o charakterze dyplomatycznym. Jeden z najbardziej charakterystycznych przykładów dotyczy stosunków pomiędzy Armenią i Turcją. Ich

26 L. Mead Tricard, American Women's Track and Field. A History, 1895 through 1980, Jefferson 1985, s. 397.

27 W.J. Baker, Sports in the Western World, Urbana 1988, s. 271.

28 G. Cavali, Cold war, warm welcome, „Stanford Magazine” maj/czerwiec 2005, http://www.stanfordalumni.org/news/magazine/2005/mayjun/features/track.html (dostęp: 16 lipca 2011); J.M. Turrini, op. cit., s. 431.

29 F. Cosentino, Hail Mary Heaven Sent, Eganville 2006, s. 104; A. Pasko, Sport wyczynowy w polityce państwa 1944-1989, Kraków 2012, s. 234-235; J.M. Turrini, op. cit., s. 439-440.

30 Ibidem, s. $441,447$.

31 K.B. Whiterspoon, „Fuzz Kids” and „Musclemen”: The US-Soviet Basketball Rivalry, 1958-1975, [w:] Diplomatic Games..., s. 299, 301. 
aktualny kształt ma podłoże historyczne i jest silnie powiązany $\mathrm{z}$ konfliktem terytorialnym pomiędzy Armenią a Azerbejdżanem o Górski Karabach. W spór ten zaangażowała się Turcja - sojusznik Azerbejdżanu, zamykając granicę z Armenią oraz nie nawiązując $\mathrm{z}$ nią stosunków dyplomatycznych ${ }^{32}$. Drugą kwestią sporną okazał się problem nieuznawania przez Turcję wydarzeń z 1915 r. na terytorium ówczesnego Imperium Osmańskiego za ludobójstwo / kwestionowania przez Turcję, iż wydarzenia, które miały miejsce w 1915 roku na terytorium ówczesnego Imperium Osmańskiego, były ludobójstwem. W ich trakcie zginęło nawet $1,5 \mathrm{mln}$ Ormian $^{33}$.

Na początku XXI w. doszło do częściowej poprawy relacji pomiędzy Turcją i Armenią. Kiedy w lutym 2008 r. na prezydenta Armenii wybrano Serzha Sarkisyana, prezydent Turcji Abdullah Gül wysłał do niego list gratulacyjny, w którym wyrażał nadzieję na normalizację stosunków między państwami ${ }^{34}$. W odpowiedzi, w lipcu 2008 r. Sarkisyan zaprosił Güla do wspólnego obejrzenia meczu piłkarskiego, rozgrywanego w ramach eliminacji do mistrzostw świata RPA 2010 (stąd określenie „dyplomacja futbolowa”) ${ }^{35}$. W Turcji wywiązała się dyskusja odnośnie do zasadności przyjęcia zaproszenia, jednak na tydzień przez terminem meczu prezydent Gül odpowiedział na nie pozytywnie. Wyraził jednocześnie nadzieję, iż jego wizyta „posłuży jako narzędzie do zniesienia barier blokujących zbliżenie pomiędzy dwoma narodami ze wspólną historią"36. Do spotkania doszło 6 września 2008 r. Po jego zakończeniu dalsze rozmowy podjęli ministrowie spraw zagranicznych Turcji i Armenii: Ali Babacan oraz Edward Nalbandian ${ }^{37}$.

W następstwie spotkania obydwu prezydentów znacząco ożywiły się kontakty dyplomatyczne pomiędzy Turcją i Armenią, czego efektem było parafowanie w październiku 2009 r. protokołów w kwestii ustanowienia stosunków dyplomatycznych oraz rozwoju wzajemnych relacji ${ }^{38}$. W tym samym miesiącu doszło też do kolejnego spotkania prezydentów Sarkisyana i Güla, podczas rewanżowego meczu piłkarskiego odbywającego się w tureckim mieście Bursa ${ }^{39}$. Zbliżenie pomiędzy krajami zostało jednak zahamowane na skutek nacisków ze strony Azerbejdżanu oraz wewnętrznych dyskusji w obu krajach. Świadczy to o tym, iż określone wydarzenie sportowe może stać się dogodną okolicznością dla zaaranżowania spotkania polityków na wysokim szczeblu i w efekcie

32 Relations between Turkey and Armenia, Republic of Turkey, Ministry of Foreign Affairs, http://www. mfa.gov.tr/relations-between-turkey-and-armenia.en.mfa (dostęp: 28 lipca 2015).

33 J.M. Dixon, Defending the nation? Maintaining Turkey's narrative of the Armenian genocide, „South European Society and Politics" 15, 2010, nr 3, s. 469.

34 S. Elanchenny, N. Maraşliyan, Breaking the Ice: The Role of Civil Society and Media in Turkey-Armenia Relations, Istanbul 2012, s. 10.

35 J. Bransten, D. Rochtus, Special report. The Turkish-Armenian rapprochement, „Middle East Critique" 19, 2010, nr 2, s. 165.

36 D.L. Phillips, Diplomatic History: The Turkey-Armenia Protocols, New York 2012, s. 42.

37 S. Elanchenny, N. Maraşliyan, op. cit.

38 T. Mkrtchyan, The Role of NGOs in Turkey-Armenia Rapprochement, [w:] Non-Traditional Security Threats and Regional Cooperation in the Southern Caucasus, red. M. Aydin, Amsterdam 2011, s. 155; L. Marchand, G. Perrier, Turkey and the Armenian Ghost. On the Trail of the Genocide, Montreal 2015, s. 104-105.

39 I. Watson, Armenian leader in Turkey for 'soccer diplomacy', CNN, http://edition.cnn.com/2009/ WORLD/europe/10/14/turkey.armenia.soccer.diplomacy/ (dostęp: 27 lipca 2015). 
podstawą do przezwyciężenia konfliktu między dwoma krajami. Jednakże dyplomacja sportowa jako narzędzie prowadzenia stosunków międzynarodowych zachowuje charakter pomocniczy i nawet jeśli jest skutecznie przeprowadzona, to bez woli politycznej i społecznej nie doprowadzi do przełomu w stosunkach politycznych.

Drugi z kluczowych przykładów wykorzystywania kontaktów sportowych do organizacji spotkań polityków związany jest ze stosunkami indyjsko-pakistańskimi. Kraje te pozostają w konflikcie właściwie przez cały okres swojej państwowości, a od ich powstania w 1947 r. doszło pomiędzy nimi do 4 wojen. Konflikt ów ma charakter terytorialny i dotyczy Kaszmiru, do którego obie strony zgłaszają pretensje ${ }^{40}$. Osobliwa „dyplomacja krykietowa”, do której doszło pomiędzy nimi, miała na celu w dużej mierze poprawę wzajemnego postrzegania się przez społeczeństwa obu krajów. Był to niewątpliwie bardzo znamienny przykład wykorzystywania wydarzeń sportowych do aranżowania spotkań dyplomatycznych, aczkolwiek, w przeciwieństwie do chociażby wspomnianych wcześniej relacji Turcja-Armenia, istniały w tym przypadku dyplomatyczne kanały kontaktu pomiędzy krajami. Wskazuje to, iż dyplomacja sportowa może prowadzić do nawiązania kontaktu politycznego w przypadku jego braku oraz w sytuacji, kiedy jest on $\mathrm{z}$ różnych względów utrudniony.

Indyjsko-pakistańska „dyplomacja krykietowa” nie odnosi się do pojedynczego wydarzenia, ale do ich ciągu obejmującego organizację serii meczów krykietowych i ich dyplomatycznej otoczki. Z tego względu na szczególną uwagę zasługują spotkania przywódców tych dwóch państw w związku wymianami krykietowymi. Do pierwszej takiej sytuacji doszło w 1987 r. w okresie wzmożonego napięcia pomiędzy krajami, związanego z przeprowadzeniem przez Indie ćwiczeń wojskowych „Brasstacks”41. To właśnie wówczas prezydent Pakistanu Muhammad Zia-ul-Haq niezaproszony przybył do Indii na odbywający się w Jaipurze mecz krykieta, mając na celu nawiązanie rozmów z indyjskimi przywódcami oraz uczynienie gestu dobrej woli ${ }^{42}$. Wizyta prezydenta Pakistanu zaskoczyła premiera Indii Rajiva Gandhiego, doszło jednak między nimi do spotkania. Co więcej, Zia-ul-Haq został ciepło przyjęty przez Hindusów ${ }^{43}$. Podczas wizyty złożono deklarację o nieatakowaniu wzajemnych instalacji nuklearnych, która została sformalizowana w grudniu $1988 \mathrm{r}^{44}$

Niemal 20 lat później ponownie doszło do wykorzystania kontaktu sportowego jako pretekstu do zorganizowania spotkania polityków z Indii i Pakistanu. Po pogorszeniu

40 S. Ganuly, Conflict Unending. India-Pakistan Tensions since 1947, Washington 2001, s. 1.

41 K.C. Dash, Regionalism in South Asia. Negotiating Cooperation, Institutional Structures, Abingdon 2008, s. 210; N. Joeck, Tacit Bargaining and Stable Proliferation in South Asia, [w:] Opaque Nuclear Proliferation. Methodological and Policy Implications, red. B. Frankel, London 1991, s. 87; S.P. Cohen, Indo-Pak Track II Diplomacy: Building Peace or Wasting Time?, [w:] Security Beyond Survival. Essays for K. Subrahmanyam, red. P.R. Kumaraswamy, New Delhi 2004, s. 197.

42 Ibidem, s. 194; C. Valiotis, Cricket in 'a Nation Imperfectly Imagined': Identity and Tradition in Postcolonial Pakistan, [w:] Cricket and National Identity in the Postcolonial Age. Following on, red. S. Wagg, Abingdon 2005, s. 126.

${ }^{43}$ P. Oborne, Wounded Tiger. A History of Cricket in Pakistan, London 2015, s. 315-316.

44 F.H. Khan, Eating Grass. The Making of Pakistani Bomb, Stanford 2012, s. 224-225; M.M. Zaki, American Global Challenges. The Obama Era, New York 2011, s. 36. 
relacji na początku XXI w., od 2004 r. organizowane były dwustronne serie spotkań krykietowych. Podczas drugiej z nich — w 2005 r. — prezydent Pakistanu Pervez Musharraf zapowiedział za pośrednictwem mediów chęć przyjazdu na mecz i przy okazji odbycia rozmów politycznych, na co strona indyjska odpowiedziała zaproszeniem. Doszło wówczas do spotkania Musharrafa z premierem Indii Manmohanem Singhem. Podczas konferencji prasowej obaj przywódcy stwierdzili, iż „proces pokojowy jest nieodwracalny" ${ }^{45}$, natomiast w parlamencie Indii Musharraf powiedział, iż „nic nie zbliża mieszkańców subkontynentu bardziej niż nasza miłość do krykieta i Bollywood"46. Oceniano, iż wizyta ta pomogła $\mathrm{w}$ konsolidacji wątłego wciąż pokoju oraz przyspieszyła proces normalizacji ${ }^{47}$.

Do trzeciego spotkania polityków indyjskich i pakistańskich przy okazji meczów krykietowych doszło w 2011 r. Wcześniej, w 2008 r., stosunki między krajami pogorszyły się w następstwie ataków terrorystycznych w Mumbaiu. Niemniej jednak w 2011 r. premier Pakistanu Yousaf Raza Gilani przyjął zaproszenie od indyjskiego premiera Singha, aby obejrzeć wspólnie półfinałowy mecz pucharu świata w krykiecie pomiędzy Indiami a Pakistanem - w Mohali w Indiach ${ }^{48}$. Podobnie jak we wcześniejszych przypadkach, spotkanie między przedstawicielami skonfliktowanych krajów zostało zorganizowane niejako przy okazji odbywającego się wydarzenia sportowego. Działo się tak w okresach, kiedy konflikt pomiędzy krajami ulegał zaostrzeniu. Nie były to jednak kontakty przełomowe, albowiem dochodziło do nich we wstępnych okresach procesu ponownej poprawy relacji. Miały one zatem przede wszystkim pogłębiający charakter, jeśli chodzi o zbliżenie pomiędzy Indiami i Pakistanem.

Konflikty i spory międzynarodowe mogą być regulowane na różne sposoby. Spośród dyplomatycznych metod ich rozwiązywania wskazuje się na rokowania międzynarodowe, dobre usługi, pośrednictwo, badania międzynarodowe i pojednanie. Rokowania polegają na bezpośredniej wymianie stanowisk i poglądów, natomiast dobre usługi stanowią wobec nich środek pomocniczy, w ramach którego strona trzecia ułatwia rozpoczęcie dialogu ${ }^{49}$. Nawiązując do powyższego wyszczególnienia, należy zauważyć, iż dyplomacja sportowa poprzez stwarzanie przywódcom politycznym państw okazji do nawiązania kontaktu działa w podobny sposób, jak metoda dobrych usług, aczkolwiek bez konieczności korzystania z pomocy strony trzeciej. Niezwykle istotne jest przy tym wykorzystanie sfery rzeczywistości pozornie apolitycznej, jaką w tym kontekście jest sport. Dzięki temu osoby zaangażowane w proces łagodzenia konfliktów między państwami unikają ryzyka związanego z utratą prestiżu w sytuacji, gdyby zainicjowane przez nich zbliżenie nie zostało pozytywnie przyjęte przez drugą stronę.

45 A. Næss-Holm, Batting for Peace. A Study of Cricket Diplomacy between India and Pakistan, Oslo 2007, s. $56-57$.

46 A. Tariq, Cricket Diplomacy, http://historypak.com/cricket-diplomacy/ (dostęp: 4 maja 2015).

47 P.R. Chari, P.I. Cheema, S.P. Cohen, Four Crisis and Peace Process. American Engagement in South Asia, Washington 2007, s. 58.

48 S. Murray, G.A. Pigman, op. cit., s. 1101.

49 K. Pawłowski, op. cit., s. 367-368. 


\section{Podsumowanie}

W niniejszym artykule zostały ukazane dwa podstawowe sposoby wykorzystywania sportu do łagodzenia konfliktów politycznych. Chodzi mianowicie o kształtowanie pozytywnego wzajemnego nastawienia społeczeństw oraz stwarzanie okoliczności umożliwiających odbywanie spotkań dyplomatycznych. Pierwszy sposób w dużej mierze dotyczy dyplomacji sportowej ujmowanej jako segment dyplomacji publicznej. Okazuje się, iż poprzez organizowanie wymian sportowych, w tym zwłaszcza pokazowych spotkań reprezentantów skonfliktowanych państw na terenie jednego z nich, tworzy się okoliczność umożliwiającą spotkanie przedstawicieli dwóch krajów, którzy często byli demonizowani przez ośrodki oficjalnej propagandy. Kiedy jednak elity polityczne dostrzegają potrzebę lub wręcz konieczność zmiany linii politycznej względem „wrogiego” kraju, niezbędne jest przygotowanie społeczeństwa do takiej zmiany. Możliwość obserwowania zawodników reprezentujących taki lub inny kraj, odnoszących się w sposób przyjacielski do kibiców i innych zawodników, pozwala na zmianę sposobu oglądu nie tylko ich, ale także krajów, które reprezentują. Następuje wówczas swoista humanizacja przedstawicieli dotychczas wrogiego państwa. Co więcej, wymiany takie pozwalają władzom na sondowanie gotowości społeczeństwa do zmiany dotychczasowej „linii politycznych działań". Ma to związek z tendencją do medializacji polityki. Należy jednak być świadomym tego, iż cele takie możliwe są do zrealizowania tylko wtedy, jeśli uda się uniknąć nastrojów nacjonalistycznych i przypisywania wynikom współzawodnictwa prestiżowego, politycznego znaczenia (wówczas może dojść do sytuacji odwrotnej i zamiast załagodzeniu konflikt polityczny ulegnie zaostrzeniu).

Obok poprawy wzajemnego nastawienia społeczeństw dyplomacja sportowa zorientowana na łagodzenie międzynarodowych konfliktów politycznych może także dostarczyć przywódcom politycznym okazji do odbywania spotkań o charakterze dyplomatycznym z przedstawicielami do niedawna wrogich państw. Tego rodzaju spotkania mogą niejednokrotnie być trudne do zaaranżowania z pominięciem sportu, który przynajmniej z pozoru pozostaje apolityczny. Często bowiem kraje uznawane za wrogie są w społeczeństwach poszczególnych krajów demonizowane, bądź też istnieją inne okoliczności utrudniające złagodzenie konfliktu, takie jak istnienie sojuszy międzynarodowych $\mathrm{z}$ ich udziałem. W związku $\mathrm{z}$ tym zaproszenia lub deklaracje przybycia na mecz sportowy mogą dać możliwość spotkania na wysokim szczeblu, a w przypadku braku dobrej woli ze strony partnera strona inicjująca taki kontakt nie ryzykuje „utraty twarzy”, swoją wizytę $\mathrm{w}$ innym kraju może bowiem uzasadniać chęcią dopingowania sportowców. Stąd też w sytuacjach relatywnie delikatnych relacji pomiędzy krajami wykorzystanie dyplomacji sportowej do zainicjowania kontaktu może uchodzić za rozwiązanie w znacznym stopniu „bezpieczne”.

Na podstawie przytoczonych przykładów łagodzenia konfliktów międzynarodowych poprzez wykorzystanie dyplomacji sportowej można stwierdzić, iż jej użyteczność dotyczy w szczególności konfliktów silnie zakorzenionych w tożsamości zbiorowej, a także pamięci zbiorowej poszczególnych społeczeństw. Pojawia się wówczas potrzeba reali- 
zacji zbliżenia międzynarodowego niejako okrężną drogą. Należy także nadmienić, iż chociaż przytoczone przykłady dotyczą dążenia do ocieplenia stosunków pomiędzy krajami wrogimi ze strony rządów, to pozytywna dyplomacja sportowa ukierunkowana na zbliżenie państw może także przybierać formę oddolnych inicjatyw, aczkolwiek ich skuteczność najczęściej jest uzależniona od politycznej woli elit. Toteż trzeba stwierdzić, iż dla skuteczności dyplomacji sportowej konieczna jest akceptacja zmiany relacji zarówno odgórnie ze strony elit, jak i oddolnie ze strony społeczeństw.

Rola dyplomacji sportowej w łagodzeniu konfliktów międzynarodowych wskazuje bez wątpienia na polityczność sportu związaną z poszukiwaniem konsensusu w stosunkach międzynarodowych. Stwierdzenie dotyczące polityczności sportu może się wydawać oczywiste. Już dawno bowiem zostało udowodnione, iż sport ma istotne znaczenie polityczne, jednakże rozważania na ten temat dotyczą przede wszystkim traktowania sportu jako elementu walki politycznej - w kontekście niniejszej analizy obejmuje to negatywną dyplomację sportową. Jednakże sport był też często wykorzystywany w celach politycznych jako narzędzie przeciwdziałania konfliktom pomiędzy państwami i łagodzenia ich, toteż jego polityczność obejmuje także współpracę międzynarodową.

\section{Bibliografia}

Axelrod A., The Real History of the Cold War. A New Look at the Past, Sterling, New York 2009.

Baker W.J., Sports in the Western World, University of Illinois Press, Urbana 1988.

Belmonte L.A., Selling the American Way. U.S. Propaganda and the Cold War, University of Pennsylvania Press, Philadelphia 2008.

Bransten J., Rochtus D., Special report. The Turkish-Armenian rapprochement, „Middle East Critique” 19, 2010, nr 2.

Cavali G., Cold war, warm welcome, „Stanford Magazine” maj/czerwiec 2005, http://www.stanfordalumni. org/news/magazine/2005/mayjun/features/track.html (dostęp: 16 lipca 2011).

Chari P.R., Cheema P.I., Cohen S.P., Four Crisis and Peace Process. American Engagement in South Asia, Brookings Institution Press, Washington 2007.

Chmaj M., Podmiotowość polityczna, [w:] Encyklopedia Politologii, t. 1, red. W. Sokół, M. Żmigrodzki, Wydawnictwo Zakamycze, Kraków 1999.

Cohen S.P., Indo-Pak Track II Diplomacy: Building Peace or Wasting Time?, [w:] Security Beyond Survival. Essays for K. Subrahmanyam, red. P.R. Kumaraswamy, Sage, New Delhi 2004.

Cosentino F., Hail Mary Heaven Sent, lulu.com, Eganville 2006.

Czajowski A., Decydowanie w polityce, Wrocławskie Wydawnictwo Naukowe Atla 2, Wrocław 2013.

D'Agati P.A., The Cold War and the 1984 Olympic Games. A Soviet-American Surogate War, Palgrave Macmillan, New York 2013.

Dash K.C., Regionalism in South Asia. Negotiating Cooperation, Institutional Structures, Routledge, Abingdon 2008.

Davies R.O., Sport in American Life. A History, Wiley-Blackwell, Malden 2007.

Dixon J.M., Defending the nation? Maintaining Turkey's narrative of the Armenian genocide, „South European Society and Politics" 15, 2010, nr 3.

Downes A.D., Forging Africa-Caribbean Solidarity within the Commonwealth? Sport and Diplomacy during the Anti-Apartheid Campaign, [w:] Diplomatic Games. Sport, Statecraft, and International Relations since 1945, red. H.L. Dichter, A.L. Johns, University Press of Kentucky, Lexington 2014. 
Elanchenny S., Maraşliyan N., Breaking the Ice: The Role of Civil Society and Media in Turkey-Armenia Relations, GPOT, Istanbul 2012.

Espy R., The Politics of the Olympic Games, University of California Press, Berkeley 1979.

Ganuly S., Conflict Unending. India-Pakistan Tensions since 1947, Columbia University Press, Washington 2001.

Houlihan B., Politics and Sport, [w:] Handbook of Sports Studies, red. J. Coakley, E. Dunning, Sage, London 2000.

Joeck N., Tacit Bargaining and Stable Proliferation in South Asia, [w:] Opaque Nuclear Proliferation. Methodological and Policy Implications, red. B. Frankel, Routledge, London 1991.

Khan F.H., Eating Grass. The Making of Pakistani Bomb, Stanford Security Studies, Stanford 2012.

L'Etang J., Sports Public Relations, Sage, Los Angeles 2013.

Marchand L., Perrier G., Turkey and the Armenian Ghost. On the Trail of the Genocide, McGill-Queen's University Press, Montreal 2015.

Mead Tricard L., American Women's Track and Field. A History, 1895 through 1980, McFarland, Jefferson 1985.

Mkrtchyan T., The Role of NGOs in Turkey-Armenia Rapprochement, [w:] Non-Traditional Security Threats and Regional Cooperation in the Southern Caucasus, red. M. Aydin, IOS Press, Amsterdam 2011.

Murray S., Pigman G.A., Mapping the relationship between international sport and diplomacy, „Sport in Society" 17, 2014, $\mathrm{nr} 9$.

Næss-Holm A., Batting for Peace. A Study of Cricket Diplomacy between India and Pakistan, VDM Verlag Dr. Müller, Oslo 2007.

Oborne P., Wounded Tiger. A History of Cricket in Pakistan, Simon and Schuster, London 2015.

Ociepka B., Miękka siła i dyplomacja publiczna Polski, Scholar, Warszawa 2013.

Pamment J., Rethinking diplomatic and development outcomes through sport: Toward a participatory paradigm of multi-stakeholder diplomacy, „Diplomacy \& Statecraft” 27, 2016, nr 2.

Pasko A., Sport wyczynowy w polityce państwa 1944-1989, Avalon, Kraków 2012.

Pawłowski K., Spory i konflikty międzynarodowe, [w:] Międzynarodowe stosunki polityczne, red. M. Pietraś, Wydawnictwo UMCS, Lublin 2007.

Payne J.G., Reflections on public diplomacy: People-to-people communication, „American Behavioral Scientist" 53, 2009, nr 4.

Phillips D.L., Diplomatic History: The Turkey-Armenia Protocols, ISHR, New York 2012.

Pigman G.A., Contemporary Diplomacy, Polity, Cambridge 2010.

Polley M., Sports History. A Practical Guide, Palgrave Macmillan, New York 2007.

Relations between Turkey and Armenia, Republic of Turkey, Ministry of Foreign Affairs, http://www.mfa. gov.tr/relations-between-turkey-and-armenia.en.mfa (dostęp: 28 lipca 2015).

Rosenberg V., Soviet-American Relations, 1953-1960. Diplomacy and Cultural Exchange During the Eisenhower Presidency, McFarland \& Company, Jefferson 2005.

Rowe D., Global Media Sport. Flows, Forms and Futures, Bloomsbury Academic, London 2011.

Santos R.B., Mestre A.M., Megalhāes F.R. de, Sports Law in Portugal, Kluwer Law International, Alphen aan den Rijn 2011.

Saxena A., The Sociology of Sport and Physical Education, Sports Publications, New Delhi 2011.

Sobkowiak L., Konflikt polityczny, [w:] Encyklopedia Politologii, t. 1, red. W. Sokół, M. Żmigrodzki, Wydawnictwo Zakamycze, Kraków 1999.

Tariq A., Cricket Diplomacy, History Pak, http://historypak.com/cricket-diplomacy/ (dostęp: 4 maja 2015).

Turrini J.M., "It was communism versus the free world": The USA-USSR dual track meet series and the development of track and field in the United States, 1958-1985, „Journal of Sport History” 28, 2001, nr 3.

Valiotis C., Cricket in 'a Nation Imperfectly Imagined': Identity and Tradition in Postcolonial Pakistan, [w:] Cricket and National Identity in the Postcolonial Age. Following on, red. S. Wagg, Routledge, Abingdon 2005.

Watson I., Armenian leader in Turkey for 'soccer diplomacy', CNN, http://edition.cnn.com/2009/WORLD/ europe/10/14/turkey.armenia.soccer.diplomacy/ (dostęp: 27 lipca 2015). 
Whiterspoon K.B., „Fuzz Kids” and „Musclemen”: The US-Soviet Basketball Rivalry, 1958-1975, [w:] Diplomatic Games. Sport, Statecraft, and International Relations since 1945, red. H.L. Dichter, A.L. Johns, University Press of Kentucky, Lexington 2014.

Xia Y., Negotiating with the Enemy. U.S.-China Talks during the Cold War, 1949-1972, Indiana University Press, Bloomington 2006.

Xu G., Olympic Dreams. China and Sports 1895-2008, Harvard University Press, Cambridge 2008.

Zaki M.M., American Global Challenges. The Obama Era, Palgrave Macmillan, New York 2011.

Ziółkowski J., Wrogość w stosunkach politycznych. Modelowa analiza funkcjonalna, DW Elipsa, Warszawa 2013.

\section{Sports diplomacy as a tool of easing international tensions}

Keywords: sports diplomacy, international tensions, public diplomacy, sport and politics

Summary

The aim of the article is to theoretically analyse the issue of sports diplomacy from the perspective of its utility in easing international tensions. The research encompass clarification of the term sports diplomacy and investigation of two ways of using it in order to ease international tensions: changing perception of hostile states within particular societies and creating opportunities for political leaders from antagonistic countries to meet, which have been described with the use of actual historical cases. 